\title{
IMPLEMENTASI TEORI MAQASHID SYARI'AH ASY-SYATIBI DALAM MUAMALAH KONTEMPORER
}

\author{
Zaenudin Mansyur \\ Fakultas Syariah UIN Mataram \\ Email: zain_nahwa@yahoo.com
}

\section{Abstract}

Maqashid Syariah Asy-Syatibi is one of the tools to monitor and balance the contemporary reality wherever and whenever. This is because the goal is very universal and can be recorded in various aspects of life, including traditional and contemporary muamalah practices. In contemporary practice, the use of Maqashid Syariab is inseparable from Muslim's needs so it can be implemented in soul maintenance (bifz an-nafs); e.g. from the threat of death in the practice of trading gecko's bile which is is believed to cure HIV AIDS. Another implementation is asset protection (bifz al-mal) in the practice of sharia insurance and sharia Reksa Dana (mutual fund). This can guarantee that one's property will return according to mutual agreement if there is an unfortunate condition. Furthermore, the implementation of Maqashid Syariah Asy-Syatibi can encourage the hifz al-mal by financing through the trading practice using internet, telephone, WhatsApp, Instagram, and SMS.

Maqashid Syariah Asy-Syatibi merupakan salah satu alat untuk meneropong dan mengimbangi realitas kontemporer itu di mana dan kapan saja. Ini karena tujuannya sangat universal dan bisa terekam dalam berbagi aspek kehidupan, termasuk dalam praktik muamalah tradisional maupun kontemporer. Dalam praktik kontemporer, penggunaan Maqashid Syariah tidak lepas dari kebutuhan Muslim sehingga diimplementasikan dalam pemeliharaan jiwa (hifz an-nafs); seperti dari ancaman kematian dalam praktik jual-beli empedu tokek yang berkhasiat menyembubkan HIV AIDS. Implementasi lainnya ialah penjagaan harta (hifz al-mal) yang terekam dalam praktik asuransi syariah maupun reksadana syariah. Ini dapat menjamin harta seseorang akan kembali sesuai perjanjian yang telah disepakati jika terjadi musibah. Selanjutnya implementasi maqashid Syari 'ah Asy-Syatibi itu dapat mendorong 
terpeliharanya harta (hifz al-mal) dengan cara pembiayaan melalui praktik jual beli dengan menggunakan via internet, telepon, WhatsApp, Instagram, dan SMS.

Keywords: Maqashid Syariah Asy-Syatibi, muamalah practice, beneficiaries,
contemporary.

\section{Pendahuluan}

Kesesuaian Islam dengan fitrah manusia adalah bentuk kongkrit kebenaran Islam sebagai sebuah aturan universal yang bisa dipakai kapanpun. Syariat Islam tidak akan pernah basi sepanjang waktu dan tidak akan usang sepanjang masa. Islam adalah ajaran yang sumbernya dari Tuhan, shalih likulli zaman wa makan, ${ }^{1}$ karena memang sifat dan tabiat ajaran Islam yang relevan dan realistis sepanjang sejarah peradaban dunia, mulai dibukanya lembaran awal kehidupan, sampai pada episode akhir dari perjalanan panjang kehidupan ini. Semua hukum, baik yang berbentuk perintah maupun larangan, yang terekam dalam teks-teks syariat bukanlah sesuatu yang hampa tak bermakna. ${ }^{2}$ Tuhan menyampaikan perintah dan larangan tertentu atas maksud dan tujuan tersebut. Asy-Syatibi menyebutnya dengan istilah Maqashid al-syariah. ${ }^{3}$

Metode tersebut terus relevan dengan kondisi zaman. Dalam Praktik muamalah teori-teori yang terkandung di dalamnya dapat dijadikan sebagai illat untuk mendukung munculnya transaksi-transaksi kontemporer. Kebutuhankebutuhan manusia yang satu dengan lainnya terus berkembang seiring perkembangan zaman yang mengitarinya. Hal itu dapat memaksa mereka untuk

1 Di antara salah satu pakar hukum Islam yang lazim menyampaikan persolan tersebut, yaitu Sedemikian pentingnya kedudukan tujuan dan perkembangan keinginan manusia sangat relevan dengan kondisi zaman yang mengitarinya. Lihat Joseph Schacht, An Inttroductian to Islamic Law (Oxford : University Press, 1996), h. 1. Bandingkan Abd. Salam Arief, Pembaharuan Hukum Islam antara Fakta dan Realita, Kajian Pemikiran Syaikh Mahmud Syaltut (Yogyakarta: LESFI, 2003), h.1.

2 Dengan demikian, melepaskan teks wahyu dari konteks sosial budaya merupakan pengabaian terhadap realitas historis. Munculnya konsep makkiyah dan madaniyyah, nâsikh mansûkh, adalah buktri kongkrit bahwa syari'at yang terekam dalam al-Qur'an tidak kosong dari ruag yang hampa melainkan sangat relevan dengan kondisi, zaman yang mengitarinya. Karena konsep makkiyah dan madaniyah tidak hanya mengkatagorikan ayat berdasarkan geografis tempat turunnya, tetapi pesannya juga terkait dengan problem kemasyarakatan di wilayah tersebut. Sementara asbâb an-nuzûl mengindikasikan adanya proses resiprokasi antara wahyu dengan realitas. Dalam kondisi ini wahyu seakan-akan memandu dan memberikan solusi terhadap problem-problem sosial yang muncul saat itu. Sedangkan nasikh mansukh merupakan proses penahapan pengiriman pesan ilahi dengan penyesuaian terhadap realitas yang berkembang. Ali Sodiqin, Antropologi Al-Qur’an Model Dialektika Wahyu dan Budaya (Yogyakarta, Ar-Ruzz Media, 2008), h. 12.

3 Ali Muttaqin, Teori Maqashid al-Syari ah dan Hubungannya dengan Metode Istinbath Hukum, Jurnal Kanun Ilmu Hukum, Vol. 19, No. 3 (Agustus, 2017), h. 547. 
adaptif dengan kondisi tersebut. ${ }^{4}$

Deklarasi ulama klasik tentang obyek transaksi wajib ada ketika transaksi berlangsung misalnya, maka tidak akan bisa diimplementasikan kembali kalau para pihak yang melakukan transaksi itu dalam lokalitas yang berjauhan. Begitu juga menjadi persoalan ketika mencermati transaksi-transaksi bisnis yang mengandalkan proses pembayarannya dengan menggunakan surat-surat berharga setidaknya dapat menolak pandangan-pandangan ulama klasik yang menitikberatkan pada proses transaksi dapat terlaksana jika rukun-rukun telah sempurna seperti obyeknya berada di tempat sekaligus suci dan tidak haram baik zat maupun sifatnya, subyeknya harus berhadapan ketika transaksi berlangsung, ijab qabul harus diucapkan dan lain sebagainya. ${ }^{5}$ Pertanyaan yang muncul kemudian adalah bagaimana mengatasi transaksi-transaksi modern yang bersebrangan dengan teori yang telah ditawarkan ulama klasik tersebut?

Kemunculan praktik muamalah kontenporer merupakan bagian terpenting dalam memberikan ruang gerak kepada masyarakat muslim dalam merubah status transaksi bisnisnya yang lebih adil, menjaga maslahah, lebih modern, bermartabat, dan mendaptkan keuntungan dunia dan akhirat. Hal ini bisa terjadi jika transaksi-transaksi bisnis yang dilakukan di internal sesama manusia mengandung maqahashid syari ah yang telah ditawarkan oleh para ulama termasuk Asy-Syatibi baik proses maupun dalam prinsipnya. ${ }^{6}$ Tetapi menjadi sangat ironis dari sekian banyak transaksi bisnis kontemporer tersebut tidak memberikan penjelasan yang kuat mengenai dasarnya sehingga tetap dipraktikkan oleh masyarakat modern saat sekarang ini. Dengan demikian, tulisan ini mengungkap sekaligus menganalisis eksistensi maqashi syari ah yang terkandung di dalam praktik muamalah kontemporer.

4 Hasbi Umar, Relevansi Metode Kajian Hukum Islam Klasik dalam Pembaharuan Hukum Islam Masa Kini", dalam Jurnal Innovatio, Vol. 6, No. 12 (Juli-Desember 2007), h. 318.

5 Pendapat para ulama yang menitikberatkan pada barangnya harus ada pada saat transaksi berlangsung itu adalah banyak dimotivasi oleh pemahamannya secara tekstual tentang hadis dari Hakim Ibnu Hizam yang menyatakan bahwa Nabi bersabda yang artinya " jangan engkau menjual barang yang tidak ada padamu. Begitu juga hadis lain yang menjelaskan tentang ketidakmampaun seseorang menampakkan barang jualannya ketika akad berlansung adalah terdapat unsur penipuan sebagaimana yang diriwayatkan Abu Hurairah tentang Sabda Rasulullah saw yang artinya: Rasulullah melarang jual beli lempar kerikil dan jual beli garar. Lihat an-Nasa 'i , Sunan an-Nasa ${ }^{i}$ (Aleppo: Maktab al-Matbu 'at al-Islamiyyat, 1406/1096), VII: 289 Hadis no. 4613. Lihat juga Muslim, Shahih Muslim (Beirut: Dar al-Fikr, 1412/1992), II Hadis No. 1513.

6 Kajian yang terfokus pada aspek kegiatan hubungan sosial antar sesame manusia dapat dikatagorikan sebagai dimensi insyaniyyah dalam maqashid as-syariah. La Jamaa, “ Dimensi Ilahi dan Dimensi Insani dalam Maqashid Al-Syari’ah “ dalam Jurna Ilmu Syariah dan Hukum Vol. 45 No. II (Juli - Desember 2011), h. 1255. 


\section{Metode Penelitian}

Jenis penelitian ini adalah library research (penelitian kepustakaan), yaitu pengkajian terhadap sumber-sumber kepustakaan yang berkaitan dengan masalah yang dibahas terutama dalam menggali konsep-konsep fiqh muamalah kontemporer dari berbagai kitab at-Turath dan buku karangan para tokoh fiqh muamalah yang berasal dari lokal maupun Barat. ${ }^{7}$ Sedangkan pendekatan yang digunakan adalah pendekatan normatif ushul figh melalui analisa induktif dan deduktif. ${ }^{8}$ Dalam hal ini, berbekal pengetahuan konsep maquạsid sharì ah Asy-Syatibi penulis mencoba menganalisa dengan cara berusaha membuktikan sejaumana perkembangan pemikiran fikih muamalah kontemporer yang diproduk oleh para tokoh dapat mengimplementasikan ushul al-khomsah yang lazim didengungkan oleh Asy-Syatibi seperti bifz ad-din, hifz an-nafs, hifz al-aql, bifz al-mal, dan bif annasl. Adapun sumber data penelitian ini adalah primer dan sekunder. Sumber primer, yakni kitab-kitab fiqh muamalah yang banyak mengkaji tentang kegiatankegiatan muamalah kontemporer. Begitu juga kajian tentang maqashid as-syariah yang dicetuskan oleh as-Syatibi sendiri maupun tokoh lain yang cenderung membahas maqashid syariah Asy-SYatibi adalah menjadi sumber primer yang tidak bisa ditinggalkan dari penelitian ini. Sedangkan sumber skunder adalah kitab atau buku yang dikarang oleh para tokoh yang memfokuskan diri dalam mengkaji pemikiran maqashid as-syariah Asy-Syatibi. ${ }^{9}$

Dengan demikian, kitab atau buku fikih muamalah kontemporer yang jadi sumber dalam peneltian ini adalah Hasan Ali Ali, AM. Hasan. Asuransi dalam Perspektif Hukum Islam, Min at-Turast: al-Iqthishad li al-Muslimin Rifa'at Audi, Islamic Economics: an Approach to Human Welfare karangan Mustafa Anas Al-Zarqa', Majmu al-Fatawa Syaikh al-Islam Ibnu Taimiyah karangan al-Asimi Al-Rahman, Abdul Ghafur. Penerapan Prinsip Syariah dalam Lembaga Pembiayaan, dan Perusabaan Pembiayaan karangan Abdul Ghofur Anshari, Lembaga Kaungan Syariah suatu Kajian Teoritis dan Praktis karangan M. Nur Raianto Aref, Hukum Bisnis Syariah karangan Burhanudin, Fatwa DSN No.20/DSN-MUI/IV/2001, Bisnis Berbasis Syari ah karangan Jusmaliani, Aspek Hukum Lembaga Keuangan Syariah di Indonesia karangan Mardani, dan lain-lain. Sedangkan buku yang terkait Maqashid asy-Syariah Asy-Syatibi adalah . al-Muwafaqat fi Ushul al-Syari ah karangan As-Syatibi, Min Atsar Fuqaha al-Andalus: Fatwa al-Imam Asy-Syatibi

7 Burhan Ahshafa, Metodologi Penelitian Hukum (Jakarta: Reneka Cipta, 1998), 15.

8 Kedua metode ini akan digunakan secara acak sesuai kebutuhan. Tentang metode-metode ini lihat Lexy J. Moleong, Metodologi Penelitian Kualitatif, Bandung: Remaja Rosda Karya, 1989, 206-215.

9 Soerjono Soekanto, Pengantar Penelitian Hukum (Jakarta: UII Press, 1986), 12. 
karangan Al-Ajfan, Maqashid al-Syari ah al-Islamiyyah wa Makarimuha karangan Al-Fasi, Maqāṣid al-Sharīah as Philosophy of Islamic Law: A Systems Approach karangan Jasser Auda, The Frimacy of The Qur'an in Syatibi Legal Theory", dalam Wael B, Hallaq dan Donald P. Little (ed) islamic Studies Persented to Charles J. Adams karangan Waell B. Hallaq, Shatibi's of Sari ah and same Imflication for Consumerr Theory karangan M. Fahim Khan.

\section{Seting Sosial Intelektual Asy-Syatibi}

Asy-Syatibi yang nama lengkapnya Abu Ishaq Ibrahim Ibn Musa alGaranati Asy-Syatibi, tanggal dan tahun kelahiran serta latar belakang kehidupan keluarganya belum banyak diketahui yang jelas keluarganya berasal dari kota Syatibah (Jativa). Oleh karena itu, ia lebih dikenal dengan sebutan Asy-Syatibi. ${ }^{10}$ Ketidakjelasan tentang kelahiran Syatibi dapat dibuktikan ketika hampir puluhan tahun dari sebelum kelahirannya, semua penduduk yang beragama Islam di daerahnya diusir dari Syatibah oleh penguasa Kristen yang berkuasa saat itu, sehingga mereka hijrah dan melarikan diri ke Granada. ${ }^{11}$ Dapat diduga kuat bahwa keluarga Asy-Syatibi bermukim sebagai penduduk Granada sampai akhir hayat mereka. Oleh karena itu, nama Asy-Syatibi dikaitkan pula dengan Kota Granada.

Kebanyakan ulama memastikan bahwa Asy-Syatibi banyak memperoleh pendidikan secara tradisional. Akan tetapi hal itu tidak berarti Asy-Syatibi tidak pernah terlibat dalam pengajaran formal. Keterlibatannya dalam pengajaran formal, terutama pengabdian dalam mengajar, dan dapat diduga dilakukannya bila dikaitkan dengan keberadaan Universitas Granada masa itu. ${ }^{12}$

Dalam meniti pengembangan intelektualnya, Asy-Syatibi adalah seorang yang sejak kecil tekun belajar, ia mendalami berbagai ilmu baik dalam bentuk ulum al-masa il wa al- 'ulum al-maqashid (metode maupun esensi dan hakikat). ${ }^{13}$ Oleh karena itu, tidak berlebihan apabila kemudian dikatakan bahwa ia memiliki Berbagai disiplin ilmu dan memahaminya secara mendalam. Asy-Syatibi adalah seorang ahli dalam bidang tafsir, ahli debat, ahli fiqih di samping sebagai ulama ushul fiqih. ${ }^{14}$ Asy-Syatibi selain tekun dan ulet dalam belajar, Asy-Syatibi juga

10 Asafri Jaya Bakri, Konsep Maqasid as-Syari ah Menurut Asy-Syatibi, (Jakarta: PT. Raja Grapindo Persada, 1996), h. 21.

11 Ahmad Syantawi, Dairah al-Ma arif (Bairut: Dar al-Fikr, tth), h. 66.

12 Musthafa al-Maraghi, al-Fath al-Mubin fi Thabaqat al-ushuliyyin (Bairut: Muhammad Amin Ramj wa Syirkah, 1974), juz II, h. 204.

13 Abi al-Ajfan, Min Atsar Fuqaha al-Andalus: Fatwa al-Imam Asy-Syatibi (Tunisia: Matba'ah alKawakiib, 1985), h. 125.

14 Asy-Syatibi, Al-I'tisham, terj., al-Mu allif (Riyad: Maktabah Riyad al-hadistah, tth), juz I, h. 10. 
seorang sosok rendah hati, jauh dari sikap keangkuhan intelektual, dan berpegang teguh pada sumber ajaran agama. ${ }^{15}$

Asy-Syatibi memulai pencarian ilmu dengan belajar mendalami bahasa Arab, pelajaran bahasa Arab ia terima dari Abu Abdillah Muhammad ibnu Fakhkhar al-Birri (w. 754 H), Abu Qashim Muhammad ibn Ahmad Asy-Syatibi (w. $760 \mathrm{H}$ ) dan Abu Ja far Ahmad al-Syaqwari. Ulama terakhir ini mengajarkan Asy-Syatibi kitab Sibawaih dan al-Fihiyah Ibnu Malik di Granada. ${ }^{16}$

Pengetahuan tentang hadits dia dapatkan dari Abu al-Qasim ibn Bina dan Syamsuddin al-Tilimsani (w. 781 h). melalui al-Tilimsani, Asy-Syatibi mempelajari al-Jami` as-Shahih al-Bukhari dan al-Muwattha karangan Imam Malik. ${ }^{17} \mathrm{Ilmu}$ kalam dan falsafah diperolehnya dari Abu Ali Mansyur al-Zawawi 9w.770 H) dan ilmu Ushul Fiqh diperolehnya dari Abu Abdillah Muhammad Ibn Ahmad Ibn Ahmad al-Miqari dan dari Imam ternama mazhab Maliki di Spanyol, yaitu Abu Abdillah Muhammad ibn al-Syarif al-Tilimsani. ${ }^{18}$ Selain mendalami ilmuilmu yang telah tersebut di atas, Asy-Syatibi juga mendalami ilmu falak, mantiq, debat, dan sastra. Pengetahuan sastra ia terima dari Abu Bakar al-Qarasyi alHasyimi, salah seorang sastrawan Spanyol. ${ }^{19}$

Pengembangan dan pendalaman ilmu dilakukan oleh Asy-Syatibi tidak hanya dalam bentuk pertemuan langsung dengan guru-gurunya akan tetapi melalui hubungan surat menyurat yang dikirim ke ulama tersohor, cara ini ditempuhnya untuk menanyakan permasalahan baik berkaitan dengan hukum

15 Ketekunan dan sikap rendah hati dan komitmennya terhadap sumber ajaran agama terlihat dari ungkapannya sendiri seperti yang dikutip oleh Abu Ajfan:" Saya selalu melatih berpikir sejak kecil dan mengarahkan upaya mencari ilmu. Saya mendalami ilmu-ilmu aqidah dan syari 'ah, ushul, dan furu 'nya, Saya tidak membatasi dengan satu cabang ilmu dengan mengabaikan yang lain, serta tidak memisahkannya sesuai dengan tuntutan masa dan tempat. Bahkan Saya terjun dalam samudera ilmu untuk berusha mampu berenang (mendalaminya). Saya melangkah dalam dunia ilmu dengan penuh keberanian, hampir-hampir Saya lebur dalam kedalamannya, melupakan keterlibatan sosial yang menyenangkan, sehingga harus Saya jembatani. Saya hilang dari pembicaraan orang, baik yang senang maupun yang benci dan menghalangi, hingga Tuhan memberikan karunia-Nya. Allah memberikan keyakinan dalam jiwa Saya bahwa kitab Allah dan Sunnah-Nya dan nabi-Nya tidak dapat ditinggalkan bagi siapapun dalam mencari hidayah-hidayah yang tidak dapat ditemukan pada selain sumber itu. Agama Islam telah sempurna, kebahagiaan yang besar telah ditetapkanNya dan apa yang disyari atkan-Nya harus diupayakan pencariannya. Selain dari yang demikian adalah sesat dan kebohongan. Abu al-Ajfan, Min Atsar, h. 90.

16 Muhammad Khalid Mas ud, Islamic Legal Fhilosophy (Islamabad: Islamic Resarch, 1977), h. 100.

17 Al-Tilimtsani yang nama lengkapnya itu Muhammad Ibnu Muhammad ibnu Qasim al-Aluni alSyariif al-hasani al-Syarif al-Tilimsani adalah ahli fiqih dan ushul fiqh bermazhab Maliki ia terkenal berpengetahuan yang luas tentang tasawuf dan falsafah. Diduga Asy-Syatibi juga memperoleh pengetahuan tentang dua disiplin ilmu tersebut dari al-Tlimsani. Karyanya bidang ushul fiqih adalah Miftah al-Ushul fi Bina al-Furu' 'ala al-Ushul . Lihat Musta al-Maraghi, al-Fath, h. 182-183.

18 Al-Ajfan, Min Atsar, h. 33-40.

19 Al-Ajfan, Min Atsar, h. 41. 
maupun dalam bidang lainnya yang memerlukan pembahasan. ${ }^{20}$

Ketokohan Asy-Syatibi sebagai ilmuwan di samping terlihat dari kegiatan belajar mengajar yang diemban dan keterlibatannya dalam memberi respon terhadap permasalahan-permasalahan keagamaan yang muncul sesuai dengan disiplin keilmuan yang di dalamnya, juga terlihat dari warisan ilmiah berupa karya ilmiah yang ditinggalkannya.

Karya ilmiah Asy-Syatibi dapat dikelompokkan ke dalam dua bagian. Pertama, karya-karya yang tidak diterbitkan dan dipublikasikan. Kedua, karya yang diterbitkan dan dipublikasikan. Termasuk dalam kelompok pertama, yaitu Syarah Jalil 'ala al-Khulashah fi al-Nabwu, Khiyar al-Majalis (sejarah kitab jual beli dari sahih Bukhari), Syarah Rajaz ibnu Malik fi al-Nabwu, 'Unwan al-ittifaq fi 'Ilm al-Isytiqaq, dan Ushul al-Nahwu. Sedangkan yang termasuk kelompok kedua adalah al-Muwafaqat fi ushul al-Syari ah, al-I tisham, al-Ifadat wa al-Irsyad. ${ }^{21}$

Kitab al-Muwafaqat fi Ushul al-Syari ah merupakan karya besar Asy-Syatibi dalam bidang ushul fiqih, dalam kitab ini Asy-Syatibi berusaha memaparkan rahasia-rahasia pentaklifan dan tujuan pensyari tan hukum oleh Allah SWT, serta aspek-aspek lain dari kajian ushul fiqh. Karya besar Asy-Syatibi ini telah membawanya sebagai ulama yang tersohor, karena di samping sebagai dasar pengembangan khazanah keilmuan di bidang hukum Islam juga sebagai bahan bacaan dan rujukan bagi para cendikiawan muslim, berikutnya di bidang ushul figh. Asy-Syatibi wafat pada tanggal 8 Sya ban $790 \mathrm{H}(1388 \mathrm{M}){ }^{22}$

\section{Pemikiran Asy-Syatibi tentang Konsep Maqashid Syari ah}

Islam sebagai agama samawi, memiliki kitab suci al-Qur`an. Sebagai sumber utama, al-Qur`an mengandung berbagai ajaran. Di kalangan ulama ada yang membagi kandungan al-Qur`an kepada tiga kelompok besar, yaitu aqidah, khuluqiyah, dan ‘maliyah. Aqidah berkaitan dengan dasar-dasar keimanan. Khuluqiyah berkaitan dengan etika dan akhlak. 'Amaliyah berkaitan dengan aspekaspek hukum yang muncul dari aqwal (ungkapan, perkataan), af al (pebuatan manusai), kelompok terakhir (amaliyah) ini, dalam sistimatika hukum Islam terbagi menjadi dua kelompok besar. Pertama, ibadat, yang di dalamnya diatur pola hubungan manusia dengan Tuhannya. Kedua, mu amalab yang di dalamnya diatur pola hubungan antara sesama manusia. ${ }^{23}$

20 Asy-Syatibi, Al-I'tishah, h. 12.

21 al-Ajfan, Min Atsar, h. 43-44.

22 Bakri, Konsep, h. 21.

23 Abdul Wahab Khallaf, Ilmu Ushul Fiqh (Kairo: Dar al-Kuwaitiyyah, 1986), h. 32. 
Al-Qur`an sebagai sumber hukum tidak memuat secara terperinci tentang ibadah dan muamalah. Dari 6360 ayat, al-Qur`an hanya terdapat 368 ayat yang betkaitan dengan aspek hukum. ${ }^{24} \mathrm{Hal}$ ini mengandung arti bahwa sebagian besar masalah-masalah hukum dalam Islam, oleh Tuhan hanya diberikan dasar-dasar atau prinsip dalam al-Qur`an. Bertitik tolak dari dasar prinsip ini, dituangkan oleh Nabi penjelasan melalui hadits-haditsnya. Berdasarkan atas dua sumber inilah kemudian, aspek-aspek hukum terutama bidang mu amalah dikembangkan oleh para ulama di antaranya adalah Asy-Syatibi yang telah mencoba mengembangkan pokok atau prinsip yang terdapat dalam dua sumber ajaran Islam itu dengan mengaitkannya dengan maqashid al-syari ah.

Secara etimologi, maqashid al-syari ah terdiri dari dua kata, yakni maqashid dan al-syari ah. Maqashid adalah bentuk jama' dari maqashid yang berarti kesengajaan atu tujuan. ${ }^{25}$ Sementara syari ah secara bahasa berarti (المو اضع تحدث من الماء) yang berarti jalan menuju sumber air. Jalan menuju sumber air ini dapat pula dikatakan sebagai jalan ke arah sumber pokok kehidupan. ${ }^{\text {.v }}$ Menurut Asy-Syatibi sebagai yang dikutip dari ungkapannya:

هذه الثريعة وضعت لتحقيق مقاصبد الثشارع فى قيام مصالحهم فى الدين و الدنيا معا

(sesungguhnya syari’at itu bertujuan mewujudkan kemaslahatan, manusia di dalam agama dan dunia sekaligus. ${ }^{28}$ Dalam ungkapan lain dikatakan oleh Asy-Syatibi : الأحكام مشرو عة لمصالح العباد (hukum-hukum itu disyari `atkan untuk kemaslahatan hamba dan agama. ${ }^{29}$

Apabila ditelaah pernyataan Asy-Syatibi tersebut, dapat dikatakan bahwa kandungan maqashid al-syaria ah atau tujuan hukum adalah kemaslahatan umat manusia. Dengan demikian, semua kewajiban (taklif) diciptakan dalam rangka merealisasikan kemaslahatan hamba. Tak satu pun hukum Allah dalam pandangan Asy-Syatibi yang tidak mempunyai tujuan. Lebih jauh ia menyatakan bahwa hukum yang tidak mempunyai tujuan sama dengan fat taklif ma la yu taq (memberikan sesuatu yang tidak dapat dilaksanakan). ${ }^{30}$

24 Harun Nasution, Islam Ditinjau dari Berbagai Aspeknya (Jakarta: UI Press, 1984), h. 7.

25 Har Wer, A. Dictionary of Modern Written Arabic. J. Milton Ciowan (London: Mac Donald, 1980), h. 767.

26 Ibnu Mansur al-Afriqi, Lisan al- 'Arab (Bairut: Dar al-Sadr, t.th), Vol: VIII, h. 175.

27 Fazzlurrahman, Islam, terj., Ahsin Muhammad (Bandung: Pustaka, 1984), h.140.

28 Asy-Syatibi, Al-Muwafaqat fi Ushul al-Syari ah (Beirut: Dar al-Ma'rifah, t.th.), h. 6.

29 Asy-Syatibi, Al-Muwafaqat, h. 54.

30 Asy-Syatibi,Al-Muwafaqat, h. 150. 
Menurut hemat penulis dapat dikatakan bahwa kandungan maqashid al-syari ab adalah kemaslahatan. ${ }^{31}$ Ajaran (doktrin) maqashid al-syari ah AsySyatibi dapat diperkuat oleh pandangan Khalid Mas`ud ia menyatakan bahwa upaya memantapkan maslahat sebagai unsur terpenting dari tujuan-tujuan hukum. ${ }^{32}$ Dengan demikian agaknya tidak berlebihan kalau kemudian B. Hallaq mengomentari bahwa maqashid al-syari $a b^{33}$ Asy-Syatibi berupaya mengekspresikan penekanan terhadap hubungan kandungan hukum Tuhan dengan aspirasi hukum manusia.

Kemaslahatan itu, melalui analisis maqashid al-syari ah tidak hanya dilihat dalam arti teknis saja, akan tetapi dalam upaya dinamika dan pengembangan hukum dilihat sebagai sesuatu yang mengandung nilai filosofis dari hukumhukum yang disyari atkan Tuhan kepada manusia.

Dalam rangka mewujudkan kemaslahatan di dunia maupun di akhirat, berdasarkan penelitian para ahli ushul fiqih, ada lima pokok yang harus dipelihara dan diwujudkan. Kelima unsur pokok tersebut adalah agama, aqal, jiwa, keturunan, dan harta. Pengejawantahan kelima unsur pokok tersebut bahwa seorang mukallaf akan mendapatkan kemaslahatan, manakala ia dapat memelihara kelima aspek pokok tersebut. Sebaliknya ia akan merasakan mafsadat, manakala ia tidak dapat melaksanakannya dengan baik. ${ }^{34}$

Pada prinsipnya Asy-Syatibi membagi maqashid al-syari ah dalam kaitannya dengan lima unsur pokok di atas menjadi tiga kelompok, yaitu dharuriyyat, hajiyat, dan tahsiniyyat. Hal ini ia maksudkan untuk memelihara atau mewujudkan kelima unsur pokok tersebut. Hanya saja peringkat kepentingannya berbeda satu dengan yang lainnya. Kebutuhan dalam kelompok pertama dapat dikatakan sebagai kebutuhan primer, yang kalau kelima unsur pokok tersebut diabaikan maka akan berakibat terancamnya eksistensi kelima pokok itu. Kebutuhan dalam kelompok kedua itu dapat dikatakan sebagai kebutuhan sekunder. Artinya, kalau kelima pokok dalam kelompok ini diabaikan, maka tidak akan mengancam eksistensinya, melainkan akan mempersulit dan mempersempit

31 Dalam kaitannya dengan masalah ini Abu Zahrah menegaskan bahwa tujuan hakiki hukum Islam adalah kemaslahatan. Tak satupun hukum yang disyari atkan baik dalam al-Qur'an dan Sunnah melainkan terdapat di dalamnya kemaslahatan. Lihat Abu Zahrah, Ushul al-Figh (Mesir:Dar alFikr al-Arabi, 1958), h. 366.

32 Muhammad Khalid Mas`ud, Islamic Legal Philosophy (Islamabad: Islamic Rsearch Institut, 1977), h. 232.

33 Well B. Hallaq “The Frimacy of The Qur'an in syatibi Legal Theory”, dalam Well B, Hallaq dan Donald P. Little (ed) islamic Studies Persented to Charles J. Adams (Liden : Ej. Brill, 1991), h. 89.

34 Al-Fasi, Maqashid al-Syari ah al-Islamiyyah wa Makarimuha (t.t: Maktabat al-Wihdat al-Arabiyyat, tth), h. 51-52. 
kehidupan manusia. Sedangkan kebutuhan dalam kelompok ketiga erat kaitannya dengan upaya untuk menjaga etiket sesuai dengan kepatutan, dan tidak akan mempersulit, apalagi mengancam eksistensi kelima unsur pokok tersebut. Dengan demikian dapat dikatakan bahwa kebutuhan dalam kelompok ketiga lebih bersifat komplementer, pelengkap. ${ }^{35}$

Dalam rangka pemahaman dan dinamika hukum Islam, pengakatagorian yang dilakukan Asy-Syatibi ke dalam tiga macam maqashid itu perlu pula dilihat dalam dua kelompok besar pembagian, yaitu segi keduniawian dan segi keakhiratan. Dari persoalan inilah kemudian Asy-Syatibi membagi maqashid al-syari ah atau tujuan hukum itu kepada dua orientasi kandungan. Kedua kandungan itu adalah; a) al-masalih al-dunniawiyah (tujuan kemaslahatan dunia), b) al-masalih al-ukhrawiyyah (tujuan kemaslahatan akhirat). ${ }^{36}$ Untuk memperoleh kedua kemaslahatan tersebut, Asy-Syatibi menggunakan empat metode melalui pemahaman maqashid al-syari ahnya, yaitu sebagai berikut;

Pertama, melakukan analisis terhadap lafal perintah dan larangan baik dalam al-Qur`an maupun Sunnah. Dalam konteks perintah maupun larangan, menurut Asy-Syatibi harus dipahami menghendaki sesuatu yang diperintahkan itu dapat diwujudkan atau dilakukan. Perwujudan isi dari perintah itu menjadi tujuan yang dikehendaki oleh al-Syar ‘i (Tuhan). Demikian pula halnya larangan, juga dapat dipahami, menghendaki suatu perbuatan yang dilarang itu harus ditinggalkan. Keharusan meninggalkan perbuatan yang dilarang merupakan tujuan yang diinginkan oleh Tuhan. ${ }^{37}$

Kedua, penelaahan illah al-amr (perintah) dan al-naby (larangan). Dalam konteks ini, diungkapkan Asy-Syatibi bahwa pemahaman maqashid al-syariah dapat pula dilakukan melalui analisis 'illah hukum yang terdapat dalam ayatayat al-Qur`an atau al-Sunnah. 'Illah hukum ini ada kalanya tertulis secara jelas dan adakalanya tidak tertulis secara jelas. Apabila ‘illah itu tertulis secara jelas dalam al-Qur'an maupun Sunnah, maka menurut Asy-Syatibi harus mengikuti apa yang tertulis itu. Karena dengan mengikuti yang tertulis itu, tujuan hukum dalam perintah dan larangan itu dapat dicapai. Sebagai contoh 'illah yang tertulis secara jelas, menurut Asy-Syatibi ${ }^{38}$ dapat dilihat dari pensyari`atan nikah yang bertujuan untuk menjaga keturunan, pemsyari atan jual beli dan kegiatan

35 Al-Fasi, Maqashid al-Syari ah al-Islamiyyah wa Makarimuha, h. 41.

36 Al-Fasi, Maqashid al-Syari 'ah al-Islamiyyah wa Makarimuha, h. 11.

37 Satria Efendi, " Kata Pengantar", dalam Murtada Mutahhari dan Baqir al-Sadr, A Short History of 'Ilm al-Ushul, terjemahan Satrio Pinandio dan Ahsin Muhammad (Jakarta: Pustaka Hidayah, 1993), h. 17.

38 Asy-Syatibi, al-Muwafaqat, h. 300. 
ekonomi lainnya, bertujuan saling memberi manfaat melalui transaksi dan lain sebagainya.

Ketiga, analisis secara sukut al-syari. Dalam kondisi ini Asy-Syatibi melakukan pemahaman terhadap permasalahan-permasalahan hukum yang tidak disebut oleh al-Syari'. Karena permasalahan hukum tersebut sangat berdampak positif dalam kehidupan. ${ }^{39}$ Dari metode ini, dapat diilustrasikan dari aktivitas-aktivitas manusia yang mendatangkan manfaat bagi kehidupannya walaupun tidak terdapat secara rinci berupa perintah dalam al-Qur`an atau Sunnah. Dalam hal ini kegiatan dalam bidang ritual, sosial, ekonomi. Misalnya dalam bidang ekonomi bahwa pemenuhan kebutuhan melalui cara-cara yang dapat mendatangkan manfaat bagi pelakunya.

Keempat, pemahaman maqashid al-syari ah dari sudut pandang ashliyyah dan tabi 'iyyah. ${ }^{40}$ Menurut hemat penulis metode pemahaman maqashid al-syari ah ini sebagai suatu sifat bukan sebagai suatu metode. Pembagian maqashid ke dalam maqashid yang mengandung kemaslahatan duniawi dan ukhrawi di atas, tidak dimaksudkan oleh Asy-Syatibi untuk menarik garis pemisah secara tajam antara dua orientasi kandungan hukum Islam tersebut. Sebab, kedua aspek tersebut secara hakiki tidak dapat dipisahkan dalam hukum Islam. ${ }^{41}$

Dengan demikian, dharuriyyat, hajiyyat, dan tabsiniyyat, maupun pembagian kepada orientasi kandungan duniawiyyat dan ukhrawiyyat adalah sangat penting. Kedua pembagian itu mewujudkan muatan skala prioritas dalam pengembangan hukum. Di samping itu menjadi informasi baru bagi para peneliti hukum Islam untuk dapat menarik garis yang jelas antara lapangan hukum yang boleh dilakukan pengembangan melalui ijtihad dan lapangan hukum yang tidak boleh dilakukan ijtihad. Adapun pembagian tersebut di atas, sebagaimana yang telah dijelaskan secara rinci, menjadi titik tolak dalam memahami hukum-hukum yang disyari' atkan oleh Allah SWT.

\section{Pemikiran Fikih Muamalah Kontemporer: Sebuah Gambaran Umum}

Fiqh muamalat kontemporer adalah aturan-aturan Allah SWT yang wajib ditaati yang mengatur hubungan manusia dengan manusia dalam kaitannya dengan kehartabendaan dalam bentuk transaksi-transaksi yang modern. Dengan

39 Asy-Syatibi, al-Muwafaqat, h. 409.

40 Asy-Syatibi, al-Muwafaqat, h. 393.

41 Keterkaitan orientasi kandungan hukum Islam tersebut merupakan perbedaan hakiki antara hukum Islam dengan hukum-hukum buatan manusia, yang bersumber kepada wahyu. Perbedaan ini disebutkan oleh Abdullah Nasih Ulwan sebagai perbedaan prinsip (Arrabbaniyyah). Abdullah Nasih Ulwan, Syari at Islam: Hukum yang Abadi, terj., Daut Rasyid (Jakarta: Usamah Press :1992), h. 69-70. 
demikian, mencermati pengertian dari fikih muamalah ini dapat memberikan indikasi bahwa seluruh kegiatan dari bisnis dalam Islam mulai dari jenis yang klasik sampai modern bertujuan bukan hanya sekedar memperoleh untung yang sebesar-besarnya, tetapi secara vertikal bertujuan untuk memperoleh ridha Allah dan secara horizontal bertujuan untuk memperoleh keuntungan sehingga bendabenda yang menjadi obyek perdagangan tadi akan senantiasa didasarkan pada aturan-aturan Allah. ${ }^{42}$

Gambaran definisi dari fikih muamalah kontemporer di atas setidaknya dapat mengarahkan kebebasan masyarakat muslim untuk memilih sekaligus menentukan transaksi mu' amalat yang dikehendakinya. Karena masing-masing orang memiliki kebutuhan dan keinginan yang tidak sama seiring dengan perkembangan zaman yang terus dihadapkan dengan era globalisasi. 43 Transaksi-transaksi mu 'amalat modern adalah salah satu contoh dari sederet transaksi yang kerap mengalami perubahan. Tetapi praktik dari transaksi yang dimaksud tidak boleh lepas dari kendali doktrin atau aturan-aturan agama sehingga tujuan yang diinginkan dari transaksi bisnis itu tidak kabur.44

Pada prinsipnya fikih muamalah merupakan aktivitas yang memiliki legalitas hukum formal mubah (boleh) dalam hukum Islam. Sebuah kaidah ushul figh yang sejak lama menjadi dasar untuk mengembalikan perkara-perkara yang membolehkan manusia untuk mempraktikkannya masih eksis diberlakukan. Dengan demikian, kaidah tersebut lazim menjadi bagian terpenting dari kebolehan seseorang untuk menentukan aktivitas mu 'amalat baik klasik sampai modern sekalipun. Adapun

42 Sama dengan teori Wazin Baihaqi menyatakan bahwa usaha yang harus dilakukan adalah Ijtihadi Hukum Ekonomi Syariah agar konteks ekonomi tetap dalam aturan Tuhan. Wazin Baihaqi", Ekonomi Islam dalam Kajian Fiqih Kontemporer Studi tentang Jaminan Fidusia”, dalam Jurnal Islamiconomic: Jurnal Ekonomi Islam, Vol 7 No. 2 (Juli-Desember 2016), h. 244.

43 Berkembangnya tujuan dan keinginan manusia seiring dengan perkembangan zaman yang mengitarinya. Itulah ungkapan yang lazim dijadikan alat oleh pakar-pakar hukum Islam dalam melegalkan suatu aktivitas praktik mu amalat Perubahan realitas merupakan bukti kongkrit yang dapat memproduk aktivitas manusia yang kian beragam. Tradisi lama berubah seketika menjadi modern karena didasarkan pada pola kehidupan yang terus dinamis. Pola pikir serta praktik sosial yang bersifat manual hijrah seketika menjadi mutakhir karena berhadapan dengan pola pikir serta praktik mu'amalat yang cenderung kontemporer. Semua itu terjadi bukan semata produk kesengajaan yang dilayangkan oleh manusia ke permukaan dunia melainkan ketetapan absolut dari pencipta alam raya ini. Di antara salah satu pakar hukum Islam yang lazim menyampaikan persolan tersebut, yaitu Sedemikian pentingnya kedudukan tujuan dan perkembangan keinginan manusia sangat relevan dengan kondisi zaman yang mengitarinya. Lihat Joseph Schacht, An Inttroductian to Islamic Law (Oxford : University Press, 1996), h. 1. Bandingkan Abd. Salam Arief, Pembaharuan Hukum Islam antara Fakta dan Realita, Kajian Pemikiran Syaikh Mahmud Syaltut (Yogyakarta: LESFI, 2003), h. 1.

44 Abu Muhammad Ali Ibn Ahmad Sa id bin Hazm, al-Muthalla (al-Qahirah: Dar al-Turats, t.th), V., h. 15. 
kaidah ushul tersebut dapat dicermati dari harfiyahnya sebagai berikut:

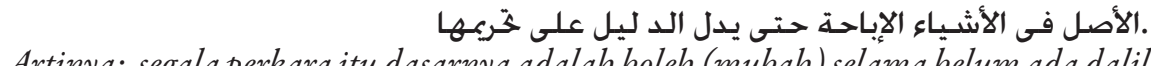
Artinya: segala perkara itu dasarnya adalah boleh (mubah) selama belum ada dalil yangmengharamkannya.

Sepintas dari kaedah ushul fiqh ini ditetapkan kebolehan melakukan suatu perbuatan dengan bara 'atul ashliyah (bebas menurut asalnya). Oleh karena itu, segala perbuatan yang ada kaitannya dengan praktik sosial atau mu' amalat menurut asalnya adalah diperbolehkan selama tidak ada dalil yang mengharamkan maupun memakruhkannya. Orang mukallaf bebas mengadakan perjanjian, perikatan atau transaksi kebendaan selama tidak ada dalil syara' yang melarang perbuatan tersebut. ${ }^{45}$ Dengan demikian memilih dan menentukan bentuk transaksi kebendaan yang kontemporer atau modern sangat tergantung dari transaksi yang akan ditransaksikan.

Jadi ranah fikih muamalah kontemporer adalah transaksi-transaksi modern yang didasarkan operasionalnya dengan menggunakan media maya seperti internet, sms, telpon dan lain-lain. ${ }^{46} \mathrm{Di}$ antara sekian banyak transaksi tersebut dapat digolongkan menjadi empat, yaitu; Pertama, adalah persoalan transaksi bisnis kontemporer yang belum dikenal zaman klasik. Lingkup ini membahas setiap transaksi yang baru bermunculan pada saat ini. Seperti uang kertas, saham, Obilgasi, reksadana, MLM, asuransi. ${ }^{47}$ Kedua, transaksi bisnis yang berubah karena adanya perkembangan atau perubahan kondisi, situasi, dan tradisi/kebiasaan. Contohnya penerimaan barang dalam akad jual beli (possesion/qabd), transaksi e-bussiness, transaksi sms. ${ }^{48}$ Ketiga, transaksi bisnis kontemporer yang menggunakan nama baru meskipun subtansinya seperti yang ada zaman klasik, misalnya bunga bank yang sejatinya adalah sama dengan riba, Jual beli Valuta Asing. ${ }^{49}$ Kemepat, Transaksi bisnis modern yang menggunakan beberapa akad secara berbilang, seperti IMBT, Murabahah lil Amiri bi Syariah..$^{50}$

45 Mukhtar Yahya dan Fathurrahman, Dasar-dasar Pembinaan Hukum Fiqh Islam (Bandung: PT. Al-Ma`arif, 1986), h. 145.

46 Hasamudin Maualana, Multiakad dalam Transaksi Kontemporer pada Lemabaga Keuangan Sayraiah di Indonesia dalam Jurnal”, Iqtishad, vol III, No. 1 Januari 2011, h. 156.

47 Mardani, Aspek Hukum Lembaga Keuangan Syariah di Indonesia (Jakarta: Prenada Media Group, 2015), h. 4.

48 Abdul Ghafur Anshari, Penerapan Prinsip Syariah dalam Lembaga Pembiayaan, dan Perusahaan Pembiayaan (Yogyakarta: Pustaka Pelajar, 2008), cet., 8.

49 Burhanudin, Hukum Bisnis Syariah (Yogyakarta: UII Press, 2011), cet 1., h. 107.

50 M. Nur Raianto ARif, Lembaga Kaungan Syariah suatu Kajian Teoritis dan Praktis (Bnadung: Pustaka Setia, 2012), h. 80. 


\section{Prinsip-Prinsip Fikih Muamalah Kontemporer}

Fikih muamalah pada prinsipnya dapat melahirkan aturan-aturan yang berkaitan dengan seluruh kegiatan manusia yang satu dengan lainnya yang menimbulkan hubungan hak dan kewajiban itu adalah bagian besar dalam kegitan hidup manusia. Meskipun demikian satu hal yang harus dicatat bahwa nilai-nilai agama menjadi sesuatu yang tidak boleh dipisahkan. Karena itu, muncullah pemikiran berbuat semata karena Allah dan orang berbuat semata untuk mengembang tugas sebagai khalifah untuk menghidupkan kegiatan muamalah. ${ }^{51} \mathrm{Hal}$ ini mengandung arti bahwa pergaulan hidup duniawi akan mempunyai akibat-akibat di akherat kelak, oleh karena itu hukum islam mengajarkan prinisp-prinsip dalam bermu' amalah. Prinsip model ini disebut dengan "prinsip syariah", yaitu tidak boleh mengandung unsur zalim yang menimbulkan ketidakadilan antara salah satu pihak, dalam kontrak harus dilakukan secara seimbang. ${ }^{52}$

Adapun prinsip fikih muamalah modern adalah sebagai berikut; ${ }^{53}$ pertama, pada dasarnya segala bentuk kegiatan mu'amalah adalah legalitasnya mubah menurut persepktif Islam. Hal ini dilandasi dalam kaedah ushul fiqh yang sejak lama dijadikan sebagai dasar untuk melegalkan kegiatan mu' amalah, yaitu: artinya” dasar hukum segala sesuatu itu adalah mubbah sampai ada dalil yang menunjukkan keharamannya. ${ }^{54}$ Kaidah ushul fiqh ini setidaknya menggambarkan adanya ruang kebebasan bagi manusia yang akan melakukan transaksi kemuamalahan kontenporer sesuai dengan tempat dan zaman di mana saja mereka berada. Artinya memilih bentuk dan jenis transaksi merupakan kehendak individu manusia yang tidak bisa dicegah. Tetapi tansaksi yang dipilihnya tidak boleh keluar dari nilai-nilai doktrin yang telah tertuang dalam al-Qur`an maupun Sunnah.

51 Swandi, Kedudukan Jaminan antara Utang Piutang dan Rahan dalam Jurnal Jurisdictie: Jurnal Hukum dan Syariah, Vol 7, No. 2 Tahun 2016, h. 211.

52 Cindawati, Perkembangan Perjanjian Baku dalam Praktek Perdagangan (Perspektif Hukum Islam dan Hukum Positif dalam Jurnal Jurisdictie: Jurnal Hukum dan Syariah, Vol 7, No. 2 Tahun 2016, h. 238.

53 Semenjak dini empat prinsip mu amalah ini telah dipraktikkan oleh Rasulullah saw. bahakan menjadi bagian dari sikap yang ditunjukkannya kepada masyarakat di zamanya. Apalgai aktivitas mu'amalahnya didukung dengan sifat-sifat keperibadiannya yang telah diabadikan dalam sejarah seperti yang dikatakan oleh Afzalurrahman bahwa perdagangan yang dilakukan Rasulullah lebih banyak menampakkan sikap shiddiq (jujur), tabligh (menyampaikan), amanah (dipercaya), fathanah (cerdas, bijaksana). Empat sikap ini menurut Afzalurrahman sebagai dasar yang mengukir kesuksesan bisnis perdagangan yang dilakukan oleh Rasulullah saw. Lihat Afzalurrahman, Muhammad sebagai Seorang Pedagang (Jakarta: Penerbit Yayasan Swarna Bhumy, 2006), h. 26.

54 Imam Musbikin, Qawa id al-Fiqhiyah (Yogyakarta: PT. Raja Grapindo Persada, 2001), h. 58. 
Kedua, mu amalah harus dilakukan atas dasar sukarela tanpa mengandung unsur paksaan. ${ }^{55}$ Prinsip kedua ini mengindikasikan bahwa kebebasan masingmasing pihak harus dihormati dengan cara menjauhi unsur pemaksaan. ${ }^{56}$ Artinya dalam melakukan proses transaksi, setiap yang melakukan transaksi harus memiliki informasi yang sama tentang kondisi barang dan jasa yang ditransaksikannya, sehingga di tengah jalan tidak ada yang merasa dirugikan. Bentuk-bentuk pelanggaran yang akan mengganggu jalannya proses transaksi menjadi kewajiban bagi kedua belah pihak untuk menghindarinya seperti terjadinya tadlis (penipuan). Karena tadlis ini terjadi disebabkan oleh : a) kuantitas pengurangan timbangan, b) kualitas: penyembunyian kecacatan barang, c) harga: memanfaatkan ketidaktahuan harga pasar, d) waktu penyerahan: penjual tidak mengetahui secara pasti barang yang akan diserahkan kepada pembeli. ${ }^{57}$

Ketiga, mu`amalah dilakukan atas dasar pertimbangan mendatangkan manfaat dan menghindari unsur-unsur mudharat dalam kehidupan bermasyarakat. Konsekuensinya bahwa segala bentuk mu'amalah yang dapat merusak kehidupan bermasyarakat adalah sangat tidak dibenarkan. Misalnya melakukan bisnis narkotika dan ganja, perjudian, dan prustitusi.

Keempat, mu' amalah dilaksanakan dengan memelihara nilai keadilan, menghindari unsur-unsur pengambilan kesempatan dalam kesempitan. Prinsip ini menentukan bahwa segala bentuk transaksi mu'amalah yang mengundang unsur penindasan tidak dibenarkan. Misalnya dalam transaksi utang piutang dengan tanggungan barang.

55 Artinya kerelaan di sini dimaksudkan adanya pengaruh sikap cinta anak manusia terhadap perbuatanperbuatan yang dicintainya, sehingga apapun yang menjadi perintah, suruhan, peraturan-Nya adalah kewajiban yang harus dita 'ati. Meskipun di sisi lain, ridha tidak harus bermakna diam, ta`at, dan menyerah tanpa ada usaha. Tetapi dengan konsep ridha yang mendarah daging dalam diri manusia serta didasari dengan usaha kuat, sehingga bisa keluar dari kesempitan menuju kelapangan, dari kehinaan menuju kemuliaan, dari mulia menjadi lebih mulia. Konsep inilah kemudian yang mendukung kuat pemahaman konsep ridha yang dilontarkan oleh Ibnu Jauzi tentang pemaknaan ridha yang berarti diam dan menyerah. Lebih jauh ia mengemukakan jika manusia berprinsip diam dan menyerah maka mereka dapat diklaim sebagai "talbis Iblis"(kebingungan yang menyesatkan). Lihat Abdul Halim Mahmud, Qadhiyah at-Tasawuf al-Munqiz min al-Dhalal lihujjat al-Islam al-Ghazali, terj., Abu Bakar Basymeleh (t.tnp.,

t.p., t.t), h. 273 .

56 Paksaan yang dimaksud adalah ancaman terhadap seseorang dengan menggunakan cara-cara yang menakutkan agar orang itu terdorong untuk melakukan atau tidak melakukan seseuatu. Lihat Mustafa az-Zarqa', al-Fiqh al-Islami fi Laubihi al-Jadid (Damaskus: Dar al-Fikr, 1967), Jilid I, h. 368 .

57 Tadlis dalam hukum Islam merupakan salah satu kegiatan mu`amalah yang dapat menimbulkan batalnya suatu perikatan bahkan menjadi perusak sekalgus sebaga dasar yang menyebabkan putusnya ukhuwah Islamiyah antar sesame. Ahmad Azhar Basyir, Azas Azas Hukum Mu amalat Hukum Perdata Islam (Yogyakarta: UII Press, 2000), h. 114-115. 


\section{Impelementasi Teori Maqashid Syari'ah Asy-Syatibi Praktik Fikih Muamalah Kontemporer}

Berkembangnya tujuan dan keinginan manusia seiring dengan perkembangan zaman yang mengitarinya. Itulah ungkapan yang lazim dijadikan alat oleh pakarpakar hukum Islam dalam melegalkan suatu aktivitas praktik muamalah. ${ }^{58}$ Perubahan realitas merupakan bukti kongkrit yang dapat memproduk aktivitas manusia yang kian beragam. Tradisi lama berubah seketika menjadi modern karena didasarkan pada pola kehidupan yang terus dinamis. Pola pikir serta praktik sosial yang bersifat manual hijrah seketika menjadi mutakhir karena berhadapan dengan pola pikir serta praktik muamalah yang cenderung kontemporer. Semua itu terjadi bukan semata produk kesengajaan yang dilayangkan oleh manusia ke permukaan dunia melainkan ketetapan absolut dari pencipta alam raya ini.

Proses untuk melakukan perubahan dalam praktik mualamah tidak semudah membalik telapak tangan. Apalagi bersentuhan dengan ranah modernitas dan kontemporer. Karenanya kebutuhan terhadap berbagai perangkat untuk mendukung terciptanya nilai-nilai kemaslahatan bagi subyek praktik mu amalat itu merupakan suatu persoalan yang tidak boleh ditawar lagi oleh siapapun yang menghendaki perubahan. Perangkat-perangkat tersebut tentunya bisa dipastikan dapat mendatangkan manfaat bagi kesejahteraan manusia. Teori maslahah yang dikumandangkan Najamuddin at-Tufi misalnya. Menurutnya secara ekstrim mengkalim bahwa setiap kegiatan yang terdapat maslahah di dalamnya adalah wajib dilaksanakan meskipun doktrin al-Qur' an maupun sunnah melarangnya. ${ }^{59}$ Teori al-Kasb Asy-Syabiani juga tidak luput dari nilai kemaslahatan. Karena menurutnya bahwa semua barang produksi yang dijadikan sebagai obyek praktik mu 'amalah adalah dapat dikatakan memiliki nilai guna harus terkandung kemaslahan bagi manusia. ${ }^{60}$ Belum lagi dengan teori Abkam as-Suq yang dilontarkan Yahya ibn Umar. Dimana teori ini berawal dari kegelisahannya melihat kondisi penetapan harga barang produksi di pasar yang kerap mendatangkan kemudharatan bagi subyek jual beli. Karena itu, ia berkesimpulan bahwa penentuan harga barang di pasar harus didasarkan dengan pertimbangan kemaslahatan bagi masing-masing

58 Di antara salah satu pakar hukum Islam yang lazim menyampaikan persolan tersebut, yaitu Sedemikian pentingnya kedudukan tujuan dan perkembangan keinginan manusia sangat relevan dengan kondisi zaman yang mengitarinya. Lihat Joseph Schacht, An Inttroductian to Islamic Law (Oxford : University Press, 1996), 1. Bandingkan Abd. Salam Arief, Pembaharuan Hukum Islam antara Fakta dan Realita, Kajian Pemikiran Syaikh Mahmud Syaltut (Yogyakarta: LESFI, 2003), h. 1.

59 Najm al-Din al-Thufi, Al-Ta'yin Fi Syarh al-Arba' in, (Beirut: Muassasah al-Rayyan, 1998), h. 277.

60 M. Fahim Khan, Shatibi 's of Sari'ah and same Imflication for Consumerr Theory, dalam Adul Hasan M. Sadeq dan Aidit Ghazali, Reading in Islamic Economic Though (Selangor Darul Ihsan: Longman Malaysia, 1992), Cet I, h. 194-196. Lihat juga Adiwarman Azwar Karim, Sejarah Pemikiran Ekonomi Islam (Jakarta: PT. Raja Grapindo Persada, 2004), h. 265. 
pihak yang akan melakukan transaksi. ${ }^{61}$

Teori dan metode modernitas dalam bidang ekonomi yang dideklarasikan oleh para ulama di atas merupakan bagian dari teori serta metodologi maqashid syari' ah yang telah ditawarkan Asy-Syatibi. Semua tujuannya dalam memproduk kegiatan mu'amalah yang terkonsentrasi pada penjagaan maslahah al-khamsah yaitu jiwa, aql, agama, harta, keturunan yang dikonstruk oleh alasan dharuriyat, hajiyat, maupun tabsiniyat. Apalagi mencermati Asy-Syatibi sendiri dalam mempergunakan teori maqashid syari'ahnya. Persoalan mengenai aspek yang dianggap penting di dalanya menjadi tanpak jelas ketika Asy-Syatibi melibatkan dirinya dalam bidang kemu amalahan khususnya dalam aspek ekonomi. Untuk melihat operasional dari maqashid as-Syari 'ahnya dalam fiqh mua' amalah dapat dicermati dalam penjelasan berikut ini.

Pertama, realitas dharuriyat dalam praktik muamalah kontemporer. Terjadinya aspek perkembangan hukum yang dinamis dalam seluruh aspek kehiupan manusia tidak lepas dari illat yang terkandung di dalamnya. Persoalan halal menjadi haram sebaliknya haram menjadi halal, mubah dan sunnah menjadi makruh dan seterusnya merupakan persoalan yang tidak bisa habis-habisnya di internal manusia. ${ }^{62}$ Semuanya berawal dari sebuah pertanyaan mendasar mengapa, dan bagaimana, serta apa hukumnya dalam sebuah persoalan hukum tersebut. Ketika berbicara tentang pertanyaan "mengapa" maka yang menjadi obyek kajiannya adalah persoalan dasar serta alasan yang benar sehingga persoalan itu tuntas untuk dilaksanakan atau dibatalkan.

Dengan demikian persoalan tersebut tidak akan pernah lepas dari teori maqashid syari ' $a b .^{63}$ Apalagi persoalan yang sedang dihadapi manusia itu berkenaan dengan aspek kegiatan mu' amalah maka faktor dharuriyat, hajiyat, dan tahsiniyat yang dikonstruk dari kemaslahatan yang lima lazim diimplementasikan. Misalnya kebebasan manusia untuk memilih praktik mu' amalah yang akan dilaksanakannya. ${ }^{64}$ Artinya setiap orang bebas menentukan siapa yang harus menjadi mitra mu' amalahnya serta penentuan waktu dan tempat pelaksanaannya. Hal ini berkonotasi pada tingkat kebutuhan masing-masing individu tersebut berbeda. Jika transaksi tersebut terkait dengan obyek yang bersifat dharuriyat, maka persoalan ini tidak

61 Rifa'at al-Audi, Min at-Turast: al-Iqthishad li al-Muslimin (Makkah: Rabitah Alam al-Islami, 1985), h. 48.

62 Muhammad Salim al Awwa, al-Fiqh al-Islami fi Thariq al-Tajdid (Birut: al-Maktab al-Ilsmai, 1998), h. 4

63 Jasser Auda, Maqāșid al-Sharī'ah as Philosophy of Islamic Law: A Systems Approach, (London: the International Institut of Islamic Thougth, 2007), h. xxi.

64 Zaenudin Mansyur, Fiqh Kebebasan Menakar Kebebasan Transaksi dalam Kegiatan Muamalah dalam jurnal”, Istinbath : Jurnal Hukum dan Ekonomi Islam, vol. 2 No. 4 Tahun 2012. 
boleh ditegah demi menjaga kemaslahatan baik yang berhubungan dengan aspek jiwa, aqal, keturuan, agama, dan harta. ${ }^{65}$ Karena itu, mengalihkan keinginan seseorang dengan cara mempropokasi serta memotivasi untuk menyimpan harta kekayaannya melalui bank syari' ah menuju bank konvensional adalah perbuatan yang memaksa dan dapat mencidrai kebebasan kehendak mereka untuk memlihara harta kekayaannya sendiri. Sementara menjaga harta kekayaan untuk lebih nyaman adalah perbuatan sangat mulia yang dihormati oleh agama. ${ }^{66}$

Begitu juga dengan pemeliharaan aspek empat yang lain tidak lepas dari proses tersebut. Misalnya menjaga aspek jiwa dari kematian akan terlihat jika transaksi yang dilakukan oleh subyek perikatan itu terkait dengan kewajiban memenuhi kebutuhan pokok sehari-hari. ${ }^{67}$ Tentu saja seseorang tidak boleh mengintervensi orang lain untuk melakukan transaksi mu'amalanya terhadap obyek kebutuhannya sebagai obat untuk mempertahankan hidupnya. ${ }^{68}$ Misalnya kebutuhan seseorang membeli tokek atau kadal hijau untuk mengobati penyakit HIV AIDS. Meskipun binatang ini merupakan barang yang sangat menjijikkan untuk dikonsumsi. Transaksi yang dilakukan ini menjadi mubah (boleh) karena illatnya menjaga kemaslahatan jiwa dari ancaman kematian HIV AIDS.

Kedua, implementasi konsep hajiyat dalam praktik muamalah kontemporer. Hajiyat merupakan bagian penting dari maqashid syari' ah yang dapat memproduk fikih muamalah secara kontemporer. Tetapi perlu dicatat bahwa konsep ini terwujud dalam fiqih mu' amalat kontenporer jika setiap pelaku dalam kegiatan transaksi modern itu dijadikan sebagai persoalan yang tidak sampai pada tingkatan dharuriyat. Hal ini terwujud ketika lembaga-lembaga asuransi atau takafful bermunculan di seluruh dunia terutama di dunia yang bermayoritas Muslim. ${ }^{69}$ Aspek fikih muamalah yang satu ini muncul didasarkan atas kehendak masingmasing pribadi muslim terutama bagi mereka yang menjadi anggota asuransi. Dimana tujuan yang hendak dicapai dalam transaksi mu amalah kontenporer ini adalah sebagai wadah yang mencoba mengakomodir kebutuhan masyarakat khususnya dalam memlihara serta menjaga harta kekayaan dari hal-hal yang tidak diinginkan oleh manusia seperti kebakaran, kebanjiran, tanah longsor, gunung

65 Al-Thufi, Syarh Mukhtashar al-Raudhah, Jilid III. (Beirut: Muassasah al-Risalah, 1989, 209). Bandingkan Musthafa Zaid, Al-Mashlahah Fi al-Tasyri'al-Islami wa Najm al-Din al-Thufi, Mesir: Dar al-Fikr al-Arabi, 1964, h. 112.

66 Jusmaliani, dkk., Bisnis Berbasis Syari ah (Jakarta: Bumi Aksara, 2008), h. 45-46

67 Adi Warman Karim, Sejarah Pemikiran Ekonomi Islam (Jakarta: PT. Raja Grapindo, 2004), h. 325 .

68 Dimyauddin Djuwaini, Pengantar Fiqh Muamalah (Yogyakarta: Pustaka Pelajar, 2008), h. 63

69 AM. Hasan Ali, Asuransi dalam Perspektif Hukum Islam (Jakarta: Kencana, 2005), h. 65. 
meletus, dan berbagai tingkatan pendidikan. ${ }^{70}$

Asuransi yang dimaksud adalah asuransi takafful yang menitik beratkan pada aspek kesyari' ahan. Artinya seluruh operasionalnya tidak menanggung garar (penipuan), maysir (perjudian), riba, zulm (penganiayaan), risywah (suap), dan barang haram dan makshiyat. ${ }^{71}$ Pemeliharaan unsur harta dalam hal ini terlihat dari kewajiban pihak lembaga takafful untuk memberikan jaminan kepada peserta yang terkena musibah. Selanjtnya apabila pihak peserta tidak mampu lagi membayar premi setiap bulannya maka peserta tersebut bisa mengundurkan diri dan modal atau investasi yang telah dikeluarkannya bisa diambil kembali dengan jumlah yang utuh. Begitu juga dalam proses pendistribusian biaya dan manfaat yang lebih adil dari terjaganya harta peserta takafful, yaitu dengan cara penentuan semakin besar kemungkinan terjadinya sutau kerugian dan semakin besar pula premi pertanggungannya. ${ }^{72}$

Pemeliharaan terhadap harta kekayaan sebagai perwujudan dalam menginplementasikan maqashid syari 'ah ketika munculnya lembaga rekasadana syari ah. Dimana lembaga ini sebagai wadah yang digunakan untuk menghimpun dana dari masyarakat pemodal untuk selanjtnya dinvestasikan dalam fortopolio efek oleh manajer investasi. Sedangkan fortopolio efek disini adalah kumpulan sekuritas berharga atau efek, atau instrumen yang dikelola. ${ }^{73}$ Dalam pengelolaannya lembaga ini dapat menginplementasikan nilai kerja sama dalam pengembangan serta pemberdayaan terhadap harta kekayaan sehingga harta yang telah terkumpul bisa berkembang dan jumlanyanya relatif bertambah. Dimana manajer investasi pihak yang mengelola uangyang terkumpul itu dari investor akan digunakan oleh manajer investasi untuk membeli surat-surat berharga seperti saham, obligasi, Sertifikat Bank Indonesia dan teknik lainnya seperti ditabungkan dalam deposito. ${ }^{74}$

Pengelolaan dana nasabah yang telah terkumpul dengan cara pihak menajer memberdayakan harta kekayaan yang dipastikan dapat menguntungkan serta jauh dari kemungkinan kerugian yang terjadi merupakan bagian yang nampak jelas dari pungsi reksadana syari' ah sebagai wadah yang memelihara unsur harta kekayaan seperti yang dikumandangkan Asy-Syatibi. Praktik ini sangat penting karena banyak masyarakat yang memiliki harta kekayaan tetapi tidak memiliki skill untuk mengelolanya. Maka dalam kondisi ini seseorang yang telah mempercayakan dananya untuk dikelola oleh manajer pengelolaan melalui

70 Andri Sumitra, Bank dan Lembaga Keuangan Sayri ah (Jakarta: Kencana,2009), h. 249.

71 Sumitra, Bank dan Lembaga Keuangan Sayri 'ah, h. 255.

72 Sumitra, Bank dan Lembaga Keuangan Sayri 'ah, h. 261.

73 Sumitra, Bank dan Lembaga Keuangan Sayri 'ah, h. 166.

74 Sumitra, Bank dan Lembaga Keuangan Sayri'ah, h. 167. 
lembaga reksa dana syari' ah adalah perwujudan dari sikap seseorang yang dapat menerapkan maqashid syari 'ah melalui hajiyat. Dengan demikian, masih banyak praktik-praktik muamalah kontenporer yang prosedur dan operasionalnya sama dengan praktik mu'amalat yang telah disebut di atas, sehingga aspek hajiyat dengan illat pemeliharaan terhadap harta kekayaan menjadi faktor penentu untuk memberlakukan maqashid syari' ah.

Ketiga, wujud tahsiniyat dalam praktik muamalah kontemporer. Prinsip tahsiniyat sebagaimana yang dijelaskan Asy-Syatibi adalah menjadi penyempurna dari aspek hajiyat. ${ }^{75}$ Karena kalau tidak ada dalam operasionalnya maka tidak sampai mengancam salah satu dari unsur pokok yang lima. Meskipun keberadaan tahsiniyat ini sebagai penyempurna tetapi ia tidak berkonotasi terhadap ketidakbergunaannya dalam proses istinbath hukum. Tetapi justru sebagai pendukung untuk memperkuat penjagaan atau pemeliharaan unsur pokok yang lima tadi. ${ }^{76}$ Salah contoh menurut Asy-Syatibi adalah shalat bagi hamba adalah aspek dharuriyat, keharusan menghadap kiblat merupakan aspek hajiyat, dan keharusan menutup aurat merupakan aspek tabsiniyat. ${ }^{77}$

Menurut penulis, contoh kasus di atas memberikan gambaran bahwa aspek tabsiniyat dalam hal ini menutup aurat sebetulnya tidak kalah pentingnya dengan dua aspek sebelumnya. Karena menutup aurat sebagai pendukung untuk penyempurnaan atau keabsahan shalat yang dikerjakan oleh seseorang, bahkan dalam tradisi fiqh menurut mayoritas ulama bahwa shalat hamba yang tidak menutup aurat tersebut menjadi tidak sah. ${ }^{78}$ Begitu juga dalam bidang mu' amalah kontenporer bahwa tabsiniyat nampak jelas operasionalnya ketika manusia melakukan transaksi-transaksi modern seperti transaksi lewat sms, telpon, maupun internet. ${ }^{79}$ Dimana transaksi

75 Mohammad Darwis, “Maqashid Al-Syariah dan Pendekatan Sistem dalam Hukum Islam Perspektif Jasser Auda dalam M. Arrfan Mua`ammar, Sudi Islam Perspektif Insider dan Outsider (Yogyakarta: IRCiSoD, 2012), h. 395.

76 Asy-Syatibi, al-Muwafaqaat ....h. 11.

77 Muhammad Al-Syafi ’ i ibn Idris, al-Umm (Kairo: Dar al-Ma rifah, 1939 H), h. $329 .$.

78 Mustafa Kamal dkk., Fikih Islam (Yogyakarta: PT. Citra Karsa Mandiri, 2002), h. 40.

79 Banyak ulama kontemporer yang berpendapat bahwa transaksi dengan piranti-piranti modern adalah sah dengan syarat ada kejelasan dalam transaksi tersebut. Di antara mereka adalah Syeikh Muhammad Bakhit al Muthi'i, Mushthofa az Zarqa', Wahbah Zuhaili dan Abdullah bin Mani'. Alasan beliau-beliau adalah sebagai berikut: 1. Berdasar pendapat banyak ulama di masa silam yang menyatakan sahnya transaksi via surat menyurat dan jika ijab (penyataan pihak pertama) adalah sah setelah sampainya surat ke tangan pihak kedua. Demikian pula mengingat sahnya transaksi dengan cara berteriak. 2. Yang dimaksud dengan disyaratkannya 'kesatuan majelis transaksi' adalah adanya suatu waktu yang pada saat itu dua orang yang mengadakan transaksi sibuk dengan masalah transaksi. Bukanlah yang dimaksudkan adalah adanya dua orang yang bertransaksi dalam 
yang dilaksanakan merupakan transaski penyempurna bagi setiap individu yang menganggapnya sebagai transaksi tambahan karena obyek transaksinya bisa saja diperoleh lewat jalan darat untuk bertemu langsung dengan penjual. ${ }^{80}$

Tabsiniyat ini sesungguhnya bisa saja berjalan seiring dengan aspek dharuriyat dan hajiyat dalam transaksi bisnis telpon, sms, internet. ${ }^{81}$ Tetapi sangat tergantung pada kondisi masing-masing subyek yang melakukan transaksi itu. Jika yang bersangkutan bertujuan untuk mempersingkat waktu agar tidak memakan waktu lama dalam melakukan transaksi maka kondisi ini bisa diklaim sebagai $d$ haruriyat. Tetapi jiak seseorang menghendaki transaksi ini sebagai tambahan dan tidak terlalu mendesak maka bisa saja masuk ke ranah hajiyat. Selanjutnya jika yang bersangkutan menjadikan transaksi ini sebagai sebuah pilihan tanpa didasari oleh persoalan-persoalan yang mendesak untuk melakukannya maka transaksi ini bisa masuk dalam ranah tahsiniyat.

Untuk mengetahui impelementasi maqashid syari 'ah secara bersamaan dalam transaksi jual beli kontenporer ini setidaknya dapat diketahui dari kewajiban individu dengan individu lain untuk mewujudkan nilai sosial dalam masyarakat seperti saling tolong menolong, saling membutuhkan, tukar menukar, dan lainlain. ${ }^{82}$ Kewajiban inilah kemudian disebut sebagai dharuriyat. Sementara ijab dan qabul dalam proses melakukan transakinya adalah termasuk ranah hajiyat. Sedangkan penggunaan model transaksi ini dapat diklasipikasikan sebagai aspek tahsiniyat.

Tahsiniyat disini nampak ketika sesorang memilih model transaksi modern tersebut dalam kondisi tidak terlalu terdesak. Jika tidak menggunakan transaksi tersebut tidak sampai pada menghilangkan salah satu dari unsur maslahah yang lima. Artinya masih ada harapan dengan menggunakan teknik lain yang bisa digunakan untuk memproleh barang yang akan ditransaksikan. Dengan adanya aspek tabsiniyat pada praktik transaksi bisnis modern ini mengkonstruk para fuqaha untuk melegalkannya agar kesejahteraan serta kesulitan yang dihadapinya bisa teratasi dengan baik.

satu tempat. Berdasarkan penjelasan tersebut maka majelis akad dalam pembicaraan via telepon adalah waktu komunikasi yang digunakan untuk membicarakan transaksi. Jika transaksi dengan tulisan maka majelis transaksi adalah sampainya surat atau tulisan dari pihak pertama kepada pihak kedua. Jika qobul tertunda dengan pengertian ketika surat sampai belum ada qobul dari pihak kedua maka transaksi tidak sah. Lihat http://ustadzaris. com/jual-beli-via-internet lihat juga Hasbi Umar, “ Relevansi Metode Kajian Hukum Islam Klasik dalam Pembahruan Hukum Islam Masa Kini”, dalam jurnal Innovatio, vol.

6. No. 12, Desember 2007, h. 318 ..

80 Adiwarman Karim, Bank Islam Analisis Fiqh dan Keuangan (Jakarta: Rajawali Press, 2004), h. 66.

81 Rahmat Syafei, Fiqh Muamalah (Bandung:Pustaka Setia, 2001), h. 224.

82 Hasbi As-Shiddiqi, Pengantar Fiqh Muamalah (Jakarta: Bulan Bintang, 1984), h. 89. 


\section{Simpulan}

Teori maqashid syari 'ah Asy-Syatibi terus relevan dalam memproduk serta menyelesaikan transaksi mu amalah mulai dari klasik sampai modern/kontenporer. Lahirnya transaksi-transaki modern dalam bidang mu' amalah seperti perbankan syari 'ah, asuransi syari 'ah, obligasi syari 'ah, reksadana syari 'ah, transaki bisnis via telpon, sms, dan via internet merupakan bagian kecil yang tidak luput dari hasil maqashid syari' ah. Karena itu, penggunaan teori maslahat yang terekam dalam teori maqashid syari 'ah Asy-Syatibi itu lazim sebagai illat untuk memproduknya. Misalnya memelihara unsur maslahat yang lima, yaitu agama, jiwa, akal, harta, dan keturunan.

Implementasi penggunaan maqashid syari' ah Asy-Syatibi dalam praktik muamalah kontenporer itu tidak luput dari kebutuhan-kebutuhan umat Islam sendiri. Misalnya dalam aspek medis yang sangat membutuhkan resep yang cocok serta dapat memberikan kesembuhan kepada penderita penyakit HIV AIDS dan salah satu obatnya menurut dokter adalah empedu Tokek. Karena itu, jual beli tokek menjadi boleh meskipun zatnya na 'jis tapi dapat karena menjaga unsur jiwa dari ancaman kematian yang disebabkan oleh penyakit HIV AIDS tersebut. Jika kesehatan sudah terjamin maka aspek penjagaan terhadap aqal, keturuan, agama, dan harta dapat terjamin. Begitu juga implementasi aspek pemeliharaan harta kekayaan atau hifz al-mal dapat dapat terhwujud dalam praktik reksadana Syari' ah dan auransi Syari 'ah karena kalau terjadi musibah yang memakan korban maka harta yang bersangkutan akan terjamin melalui praktik tersebut. Sedangkan implelemntasi aspek tahsiniyat yang digagas Asy-Syatibi terekam dalam parketk jual beli persoalan jual beli via internet, telpon, whatsaap, istagram, media sosial lainya. Hal ini terlihat sebagai sebagai pendukung untuk penjagaan harta kekayaan atau hifz al-mal dengan cara memanfaatkannya sesuai kebutuhan sehingga dapat mengindari muflis atau boros..

\section{Daftar Pustaka}

Abdad, M.Zaidi.Lembaga Perekonomian Ummat di Dunia Islam, Bandung: Angkasa, 2003

Ahmad, Syantawi. Dairah al-Ma 'arif. Bairut: Dar al-Fikr, tth.

Ali, AM. Hasan. Asuransi dalam Perspektif Hukum Islam, Jakarta: Kencana, 2005

Al-Audi, Rifa'at. Min at-Turast: al-Iqthishad li al-Muslimin. Makkah: Rabitah Alam al-Islami, 1985. 
Al-Zarqa ', Mustafa Anas. Islamic Economics: an Approach to Human Welfare, dalam Aidit Gazali dan Sayyid Umar. Rreadings The Concept an Methodology of Islamic Ekonomics. Selangor Darul Ihsan: Pelanduk Policiation, 1989.

Al-Fasi. Maqashid al-Syari' ah al-Islamiyyah wa Makarimuha.t.t: Maktabat al-Wihdat al-Arabiyyat, tth.

Al-Afriqi, Ibnu Mansur. Lisan al- 'Arab, Bairut: Dar al-Sadr. t.th, Vol: VIII.

Al-Maraghi, Musthafa. al-Fath al-Mubin fi Thabaqatal-Ushuliyyin. Bairut: Muhammad Amin Ramj wa syirkah, 1974, juz II.

Al-Ajfan, Abi. Min Atsar Fuqaha al-Andalus: Fatwa al-Imam Asy-Syatibi. Tunisia: Matba' ah al-Kawakiib, 1985.

Al-Qurdi, Ahmad al-Hajj. al-Madkhal al-Fiqhi al-Qawa 'id al-Kulliyat. Damsyiq: Dar al-Ma' arif, 1980.

Al-Rahman, Al-Asimi. Majmu' al-Fatawa Syaikh al-Islam Ibnu Taimiyah. juz xx, ttp.

Al-Thufi, Najm al-Din. Al-Táyin fi Syarh al-Arbain. Beirut: Muassasah al-Rayyan, 1998

Al-Thufi, Najm al-Din. Syarh Mukhtashar al-Raudhah, Jilid III., Beirut: Muassasah al-Risalah, 1989, 209.

Anshari, Abdul Ghafur. Penerapan Prinsip Syariah dalam Lembaga Pembiayaan, dan Perusahaan Pembiayaan, Yogyakarta: Pustaka Pelajar, 2008.

Arief, Abd. Salam . Pembaharuan Hukum Islam antara Fakta dan Realita: Kajian Pemikiran Syaikh Mahmud Syalthout. Yogyakarta: LESFI, 2003.

Arif, M. Nur Raianto. Lembaga Kaungan Syariah suatu Kajian Teoritis dan Praktis (Bnadung: Pustaka Setia, 2012

Ahshafa, Burhan. Metodologi Penelitian Hukum, Jakarta: Reneka Cipta, 1998.

As-Suyuthi, Jalauddin. Al-Radd 'ala Man Akblada ila al-Ardi wa Jahila 'An Ijtihad fi Kull 'Asrin Fard. Bairut: Dar al-Fikr, 1983.

Asy-Syatibi. al-Muwafaqat fi Ushul al-Syari ah. Beirut: Dar al-Ma rifah, t.th., Juz I, II, 
Asy-Syatibi, Al-'Tisham. Terjemahan oleh al-Mu'allif. Riyad: Maktabah Riyad alhadistah, tth), juz I

Auda, Jasser. Maquașid al-Shariah as Philosophy of Islamic Law: A Systems Approach, (London: the International Institut of Islamic Thougth, 2007.

Baihaqi, Wazin. ", Ekonomi Islam dalam Kajian Fiqih Kontemporer Studi tentang Jaminan Fidusia", dalam Jurnal Islamiconomic: Jurnal Ekonomi Islam, Vol 7 No. 2, Juli-Desember 2016.

B. Hallaq, Waell. "The Frimacy of The Qur'an in Syatibi Legal Theory", dalam Wael B, Hallaq dan Donald P. Little (ed) islamic Studies Persented to Charles J. Adams . Liden: Ej. Brill, 1991.

Bakri, Asafri Jaya. Konsep Maqasid as-Syari ah Menurut Asy-Syatibi. Jakarta: PT. Raja Grapindo Persada, 1996.

Burhanudin, Hukum Bisnis Syariah, Yogyakarta: UII Press, 2011.

Cindawati, Perkembangan Perjanjian Baku dalam Praktek Perdagangan (Perspektif Hukum Islam dan Hukum Positif dalam Jurnal Jurisdictie: Jurnal Hukum dan Syariah, Vol 7, No. 2 Tahun 2016.

Colson, Nj. A History of Islamic Law. Elinburgh : University Press, 1964.

Depag RI. Al- Qur' an dan Terjemahannya. Depag. RI 1995.

Djuwaini, Dimyauddin. Pengantar Figh Muamalah (Yogyakarta: Pustaka Pelajar, 2008

Fatwa DSN No.20/DSN-MUI/IV/2001

Hazm, Abu Muhammad Ali Ibn Ahmad Sa'id bin. al-Muthalla (al-Qahirah: Dar al-Turats, t.th), V., 15.

Jusmaliani, dkk., Bisnis Berbasis Syari 'ah, Jakarta: Bumi Aksara, 2008.

Karim, Adi Warman. Sejarah Pemikiran Ekonomi Islam. Jakarta: PT. Raja Grapindo, 2004.

Khan, M. Fahim. Shatibi's of Sari 'ah and same Imflication for Consumerr Theory, dalam Adul Hasan M. Sadeq dan Aidit Ghazali, Reading in Islamic Economic Though. 
Khallaf, Abdul Wahab. Ilm Ushul Figh. Kairo: Dar al-Kuwaitiyyah, 1986.

Khallaf, Abdul Wahab. Mashadir at-Tasyri ' fi ma La Nassa fibi.. Kuwait: Dar al-Qalam, 1972 .

LaJamaa, "Dimensi Ilahi dan Dimensi Insani dalam Maqashid Al-Syari ah " dalam Jurna Ilmu Syariah dan Hukum Vol. 45 No. II (Juli - Desember 2011), 1255.

Mansyur, Zaenudin. Fiqh Kebebasan Menakar Kebebasan Transaksi dalam Kegiatan Muamalah dalam jurnal", Istinbath: Jurnal Hukum dan Ekonomi Islam, vol. 2 No. 4 Tahun 2012.

Mardani, Aspek Hukum Lembaga Keuangan Syariah di Indonesia (Jakarta: Prenada Media Group, 2015.

Mas`ud, Muhammad Khalid. Filsafat Hukum Islam: Studi Tentang Hidup dan Pemikiran Asy-Syatib. Bandung: Penerbit Pustaka, 1996.

Mas'ud, Muhammad Khalid. Islamic Legal Philosophy. Islamabad: Islamic Rsearch Institut, 1977.

Mas'ud, Muhammad Khalid. Pembaharuan dalam Islam, Sejarah Pemikiran dan Gerakan. Jakarta: Bulan Bintang, 1975.

Maualana, Hasamudin. Multiakad dalam Transaksi Kontemporer pada Lemabaga Keuangan Sayraiah di Indonesia dalam Jurnal", Iqtishad, vol III, No. 1 Januari 2011.

Moleong, Lexy J. Metodologi Penelitian Kualitatif, Bandung: Remaja Rosda Karya, 1989.

Muttaqin Ali,, Teori Maqashid al-Syari ah dan Hubungannya dengan Metode Istinbath Hukum, Jurnal Kanun Ilmu Hukum, Vol. 19, No. 3, Agustus, 2017.

Schacht, Joseph. An Introductian to Islamic Law. Oxford : University Press, 1996.

Soekanto, Soerjono. Pengantar Penelitian Hukum, Jakarta: UII Press, 1986.

Swandi. Kedudukan Jaminan antara Utang Piutang dan Rahan dalam Jurnal Jurisdictie: Jurnal Hukum dan Syariah, Vol 7, No. 2 Tahun 2016, 211.

Umar, Hasbi. Relevansi Metode Kajian Hukum Islam Klasik dalam Pembaharuan Hukum Islam Masa Kini", dalam Jurnal Innovatio, Vol. 6, No. 12 (Juli-Desember 2007. 
Yanggo, Huzaimah Tahindo. Asuransi Hukum dan Perkembangannya dalam Jurnal Al-Abkam, Vol., VII, No. 12 Taun 2003. 